\title{
Impact of Education for Adherence to Therapy Based on Health Promotion Model on the Quality of Life in HIV-infected Patients
}

Farideh Esmaili

MSc in Health Education, Dept. of Health Education \& Health Promotion, School of Health, Bushehr Province University of Medical Sciences (BPUMS), Bushehr, Iran

\section{Rahim Tahmasebi}

Associate Professor, Dept. of Biostatistics, School of Health, and a Member of the Persian Gulf Tropical Medicine Research Center, BPUMS, Bushehr, Iran

\section{Azita Noroozi}

*Associate Professor in Health Education, \& Health Promotion, School of Health, BPUMS, Bushehr, Iran (Corresponding author)

azitanoroozi@yahoo.com

Katayon Vahdat

Professor of the Persian Gulf Tropical Medicine Research Center, BPUMS, Bushehr, Iran

Behrooz Kavehie

Assistant Professor in biostatistics, National Organization for Educational Testing, Tehran, Iran

Received: $\mathbf{2 5}$ November 2015

Accepted: 16 November 2016

\section{ABSTRACT}

Background and objective: The use of antiretroviral drugs may affect the quality of life of HIV-infected patients. The aim of this study was to evaluate the impact of education for adherence to therapy based on health promotion model on quality of life of HIV-infected patients under antiretroviral therapy (ART) in the city of Bushehr, Iran.

Materials and methods: This study was a quasi-experimental study which had been carried out on 61 HIV positive patients under ART. In the intervention group, face to face training of 31 patients was carried out based on health promotion model through two education sessions with a two-week interval also with an educational booklet of adherence to therapy; and 30 members of the control group received routine cares of the health center during the study period. Data collection tool in this study consisted of demographic characteristics, constructs related to health promotion model, and quality of life questionnaire (SF36). Questionnaires about constructs were answered before, immediately, and three months after education. Questionnaires about adherence to therapy and quality of life were answered before, and three months after education. The data were analyzed by using descriptive statistics, independent $t$ test, chisquare test, ANOVA with repeated measure, and paired t test through SPSS18. Results: Education caused significant changes in all constructs of health promotion model including belief to therapy, benefits and barriers to adherence, social support and self-adherence $(p<0.001)$ and positively changed people's attitudes towards therapy. Quality of life in physical, general health, emotional and mental health factors also increased significantly among education (intervention) group ( $p<0.001)$.

Conclusion: The findings of this study indicate the effectiveness of training programs to enhance the quality of life of patients in which this change had been achieved through impact on patients' beliefs and attitudes on adherence to therapy.

Paper Type: Research Article.

Keywords: Quality of life, Positive HIV, Adherence to therapy, Health promotion model, Quality of life Short Form (36) Health Survey (SF36), Bushehr.

Citation: Esmaili F, Tahmasebi R, Noroozi A, Vahdat K. Impact of education for adherence to therapy based on health promotion model on the quality of life in HIV-infected patients. Iran J Health Educ Health Promot. Autumn 2016;4(3): 173-183. 


\section{تأثير آموزش بإيبندى به درمان مبتنى بر الكوى ارتقاء سلامت بر كيفيت زندكى

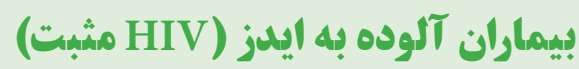

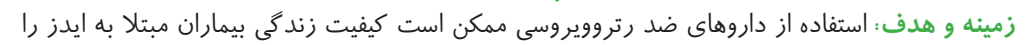

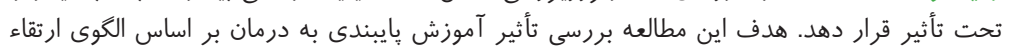

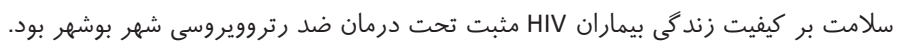

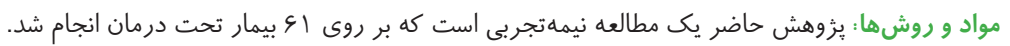

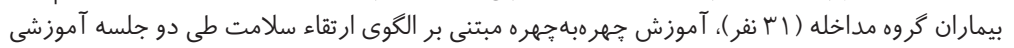

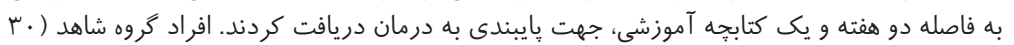

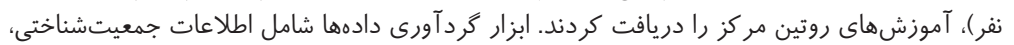

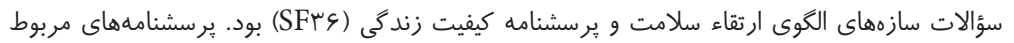

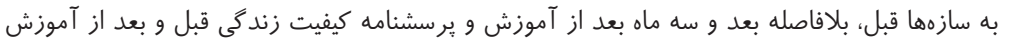

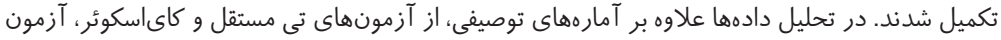

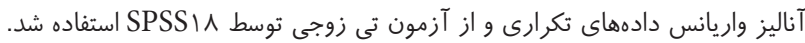

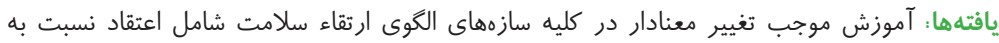

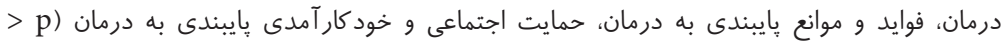

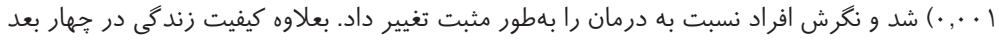

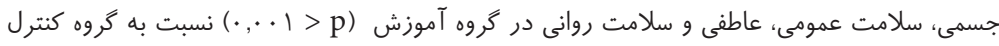

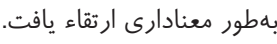

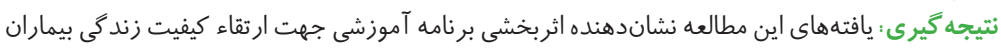

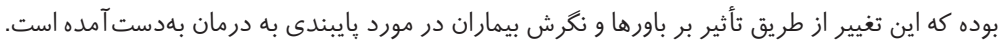

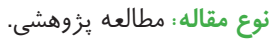

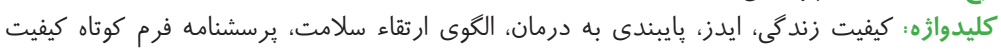

فريده اسماعيلى

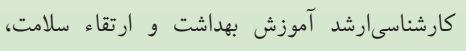

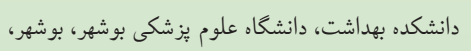
دانشيار كروه آمار زيستى، دانشكده بهداشت و عضو

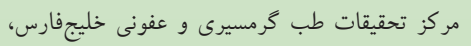
دانشكاء علوم يُشكى بوشهر، بوشهر، ايران

\section{آزيتا نوروزى}

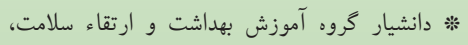

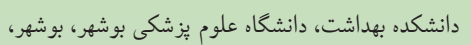
azitanoroozi@yahoo.com

$$
\text { ايران (نويسنده مسئول) }
$$

$$
\text { كتايون وحدت }
$$

استاد مركز تحقيقات طب كرمسيرى و و عفونى خليجفارس، دانشكاء علوم يزشكى بوشهر، بوشهر، ايران

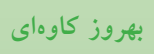
دانشيار آمار زيستى، سازمان سنجش آموزش كشور، تهر ان، ايران

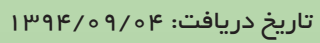

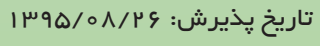


است (ه-A). ازجمله يافتهاى مطالعه من هايمر 'و همكاران (ه) بر روى بايبندى به درمان ضد رتروو يروسى و كيفيت زندگى در

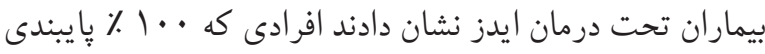

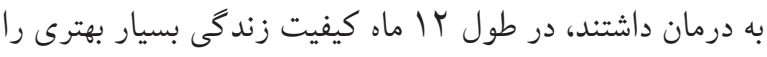
نسبت به كسانى كه كمتر از •^ ٪ پا يبندى به درمان داشتند بيان داشته بودند؛ و بهطور كلى پايبندى به درمان با افزايش كيفيت

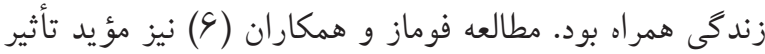
مثبت دو روش درمانى در يايبندى به درمان و كيفيت زندگى

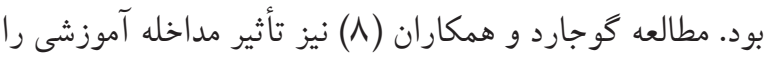
در پايبندى به درمان و كيفيت زندگى بيماران تحت درمان ايدز

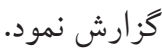
در هيج يك از اين مطالعات بيان شده از الكوهاى تغيير رفتار

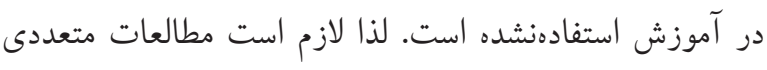

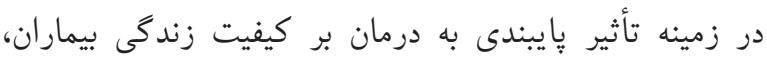
بهويزه با استفاده از الكوها و نظريههاى مختلف، انجام شود تا بان

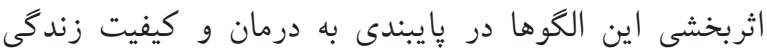

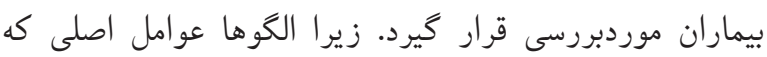

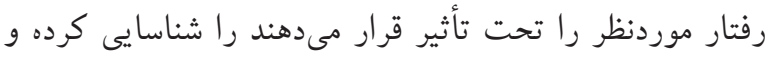

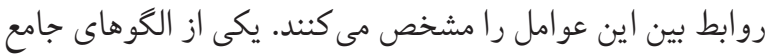
و ويشكويى كننده كه جهت رفتارهاى ارتقاءدهنده سلامت استفاده مىشود، الكوى ارتقاء سلامت يُروفسور يُندر است. در اين الكو، رفتار ارتقاءدهنده سلامت تحت تأثير سه عامل قرار مى گيرند () تجربها و ويثگى هاى فردى، Y) شناخت و عواطف خاص رفتار و r ب يُامد رفتارى يا رفتار ارتقاءدهنده سلامت. مفهوم

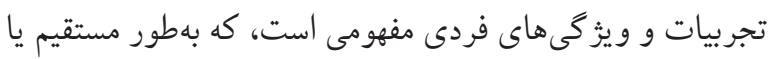

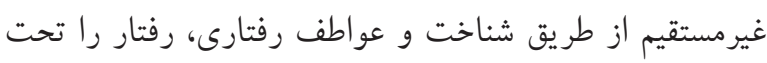

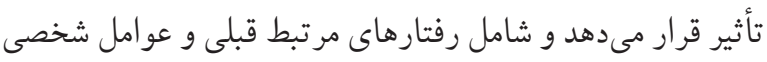
ازجمله عوامل زيستشناختى، روانشناختى، اجتماعى - فرهنكى و ويزگگهاى عمومى فرد مانند سن، جنس، نزاد و وضعيت روسي

1. Mannheimer

2. antiretroviral therapy (ART)
بر اساس آخرين آمار گزارششده توسط سازمان جهانى بهداشت،

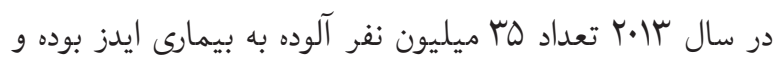

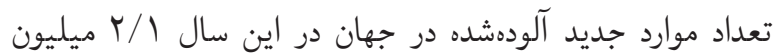
نفر و تعداد موارد فوتشده ه/ ميليون نفر بوده است. امروزه تعداد IT/9 ميليون نفر در جهان داروى ضد رتروويروسى دريافت

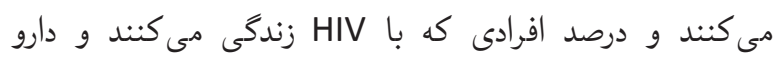

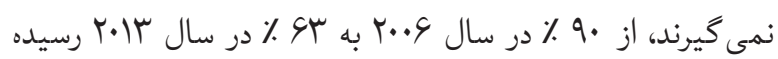
است ( (). در ايران نيز تخمين زده مىشود كه D ه هزار نفر مبتلا

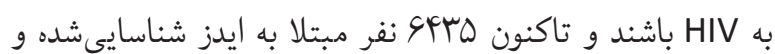

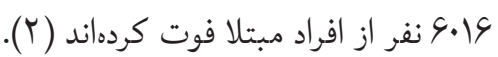
كيفيت زندكى در طول دو دهه كذشته از مهمترين

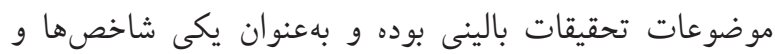

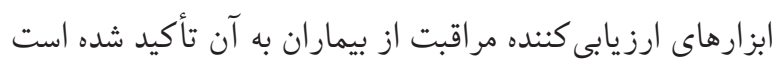

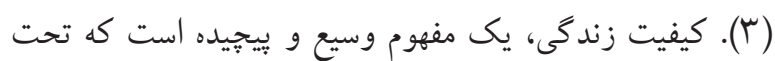

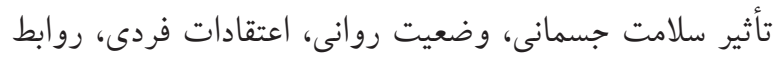

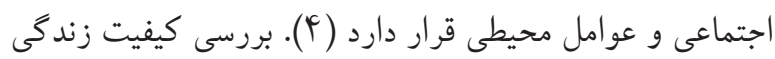

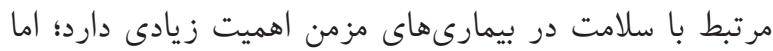
مطالعات كمى در مورد كيفيت زندگى بيمار ان مبتلا به HIV انجام

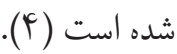
وايبندى به درمان يك جزء حياتى در بيمارى ايدز است. و و از طرفى، هدف از درمان در كليه بيمارىهاى مزمن ازجمله ايدز

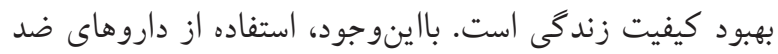
رتروويروسى در بيماران مبتلا به HIV به دليل عوارض جانبى

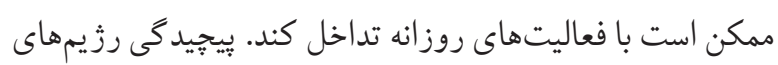
درمانى نيز كيفيت زندكى را تحت تأثير قرار داده و خود بهعنوان يك مانع براى يا يبندى به درمان عمل مى كند (ه- (9). ارتباط بين

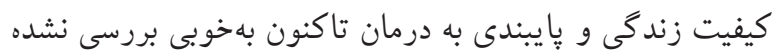

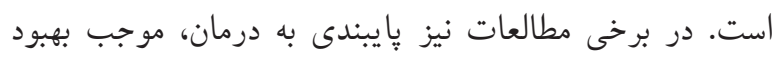

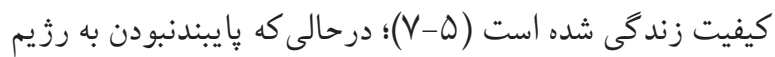

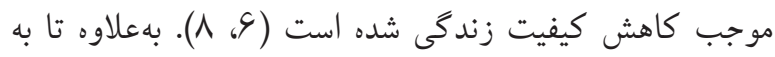


طول مدت مصرف داروى ضد رتروويروسى در زمان مطالعه،

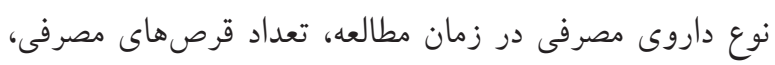

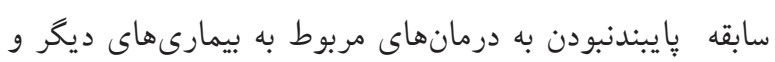

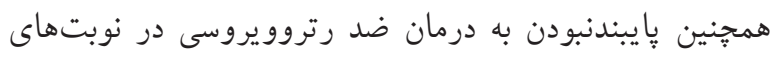
قبلى را موردبررسى قرار كرفتند.

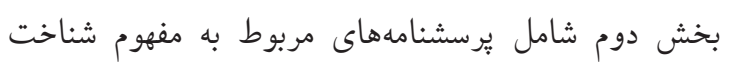

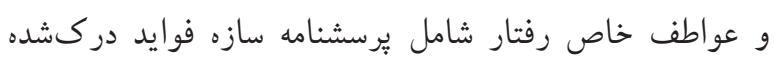

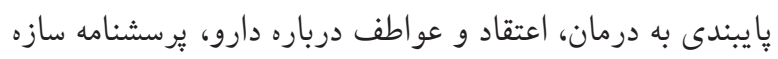

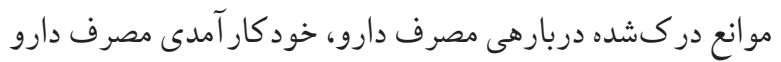

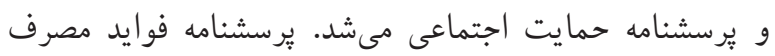

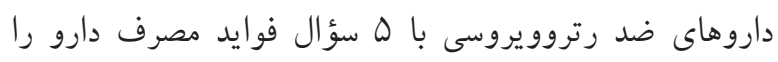

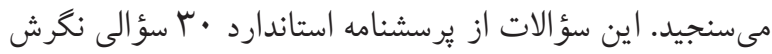
نسبت به دارو استخراج شد. سؤالات اين سازه با مقياس ليكرت

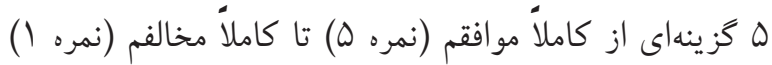

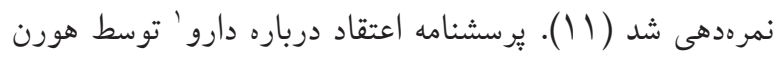

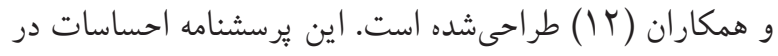

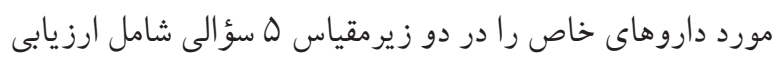

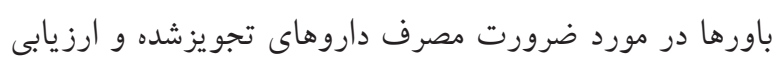
نغر انىها در مورد عوارض طور لانىمدت دورد داروها بررسى مى كند.

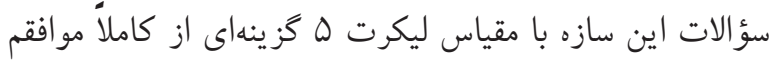

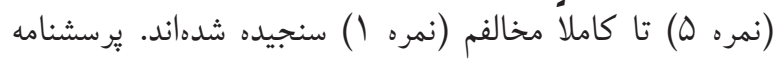

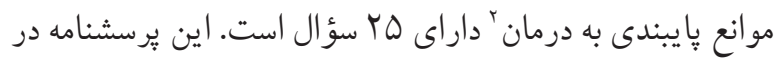

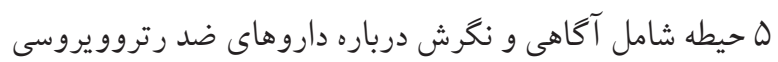

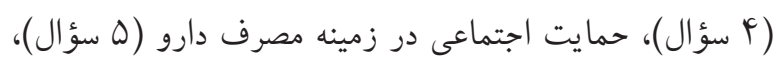
كيفيت داروها (ه سؤال)، مسائل مربوط به برنامهريزى (4) (هائل

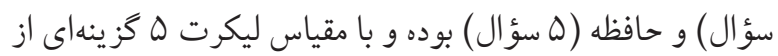
كاملاً موافقم (نمره ه) تا كاملاً مخالفم (نمره ا ) سنجيده مى شوند

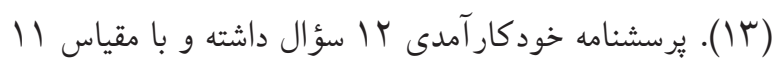
نقطهاى با نمره صفر (كاملاً نمى توانم انجام دهم) تا ده (كاملاً

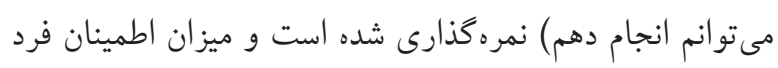

1. Beliefs about Medication Questionnaire (BMQ)

2. Patient Medication Adherence Questionnaire (PMAQ)
اجتماعى - اقتصادى است. مفهوم احساسات و شناختهاى

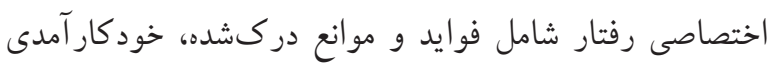

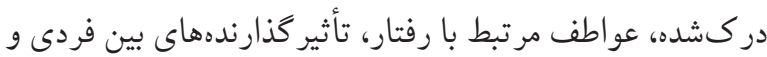
تأثير كذارندههاى موقعيتى است (9، • (1).

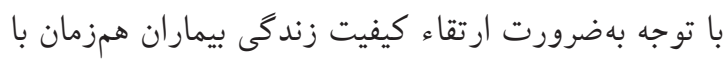
افزايش يا يبندى به درمان و از طرفى نبود مطالعات نظر يهمحور

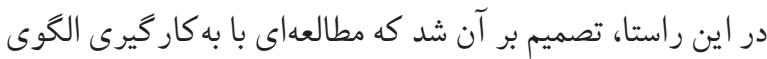

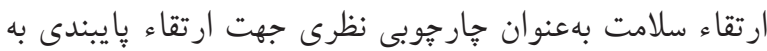

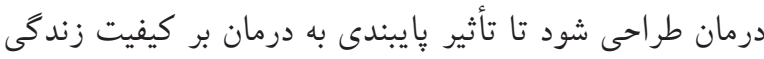

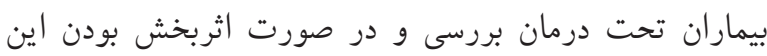

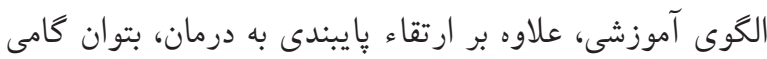

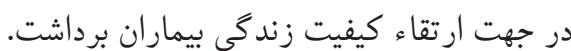
مو اد و روش ها اين مطالعه يزوهشى نيمهتجربى بود؛ كه بر روى لو بون نفر از بيماران HIV مثبت تحت درمان ضد رتروويروسى مركز مشاوره

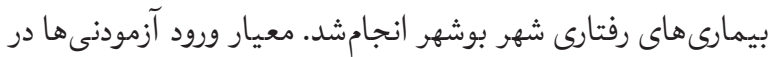

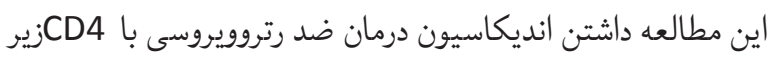

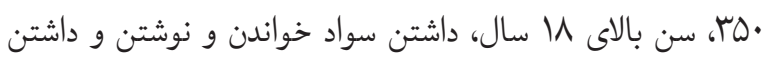
سلامت روحى- روانى و معيار خروج نداشتن رضايت جهت شركت در مطالعه بود. به دليل محدود بودن تعداد بيماران تحت درمان،

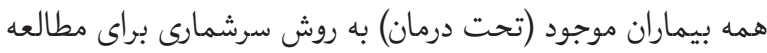

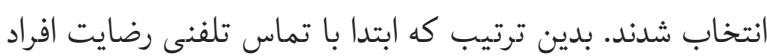

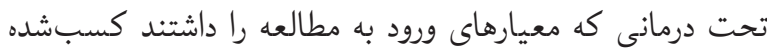
و سيس افرادى كه حاضر به شركت در مطالعه بودند با روش

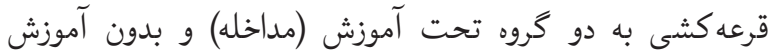
(شاهد) تقسيم شدند.

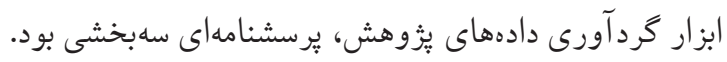

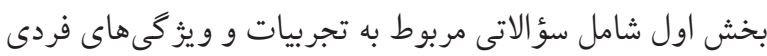
با ها سؤال است و شامل سن، جنس، وضعيت تأهل، ميزان تحصيلات، داشتن اعتياد و نوع ماده مصرفى، وضعيت شغلى، 
اعضاى ڤانل خبر گان بررسى و نسبت روايى محتوايى و شاخص

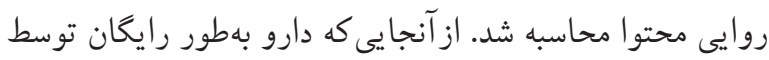
مركز مشاوره بيمارىهاى رفتارى در اختيار بيماران قرار داده دهاه

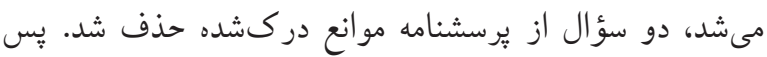

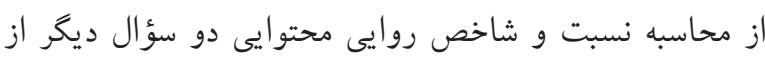

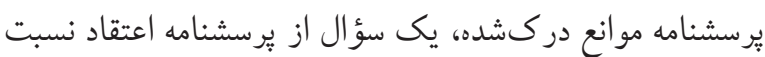
به دارو و يك سؤال از يرسشنامه حمايت اجتماعى حذف شدند.

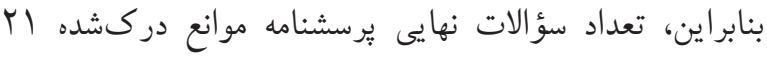

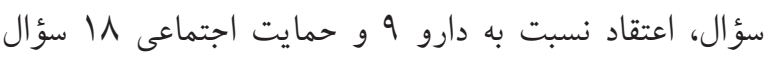
شدند. جهت تعيين پايايى ابزار نيز يك نمونه يُرسشنامه نهايى در اختيار ^ نفر از بيماران تحت درمان ضد رتروويروسى قرار بردين

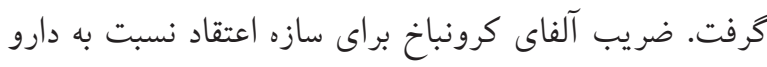

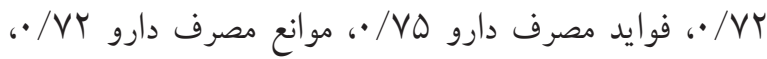
حمايت اجتماعى 90/ • و خود كار آمدى 9 / / • بود. دوان.

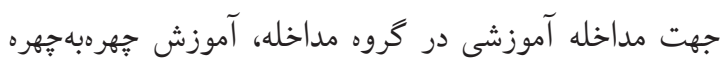
براى اس نفر از بيماران تحت درمان طى دو جلسه آموزشى به درونه فاصله دو هفته انجام شد. بعد از حضور افراد در مركز مشاوره، ابتدا اهداف مطالعه براى ايشان توضيح دادهشد. سيس از آنها خواسته

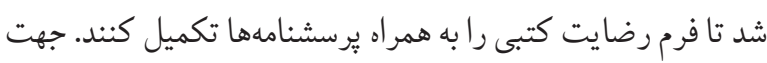

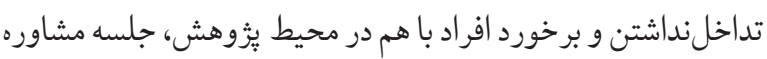

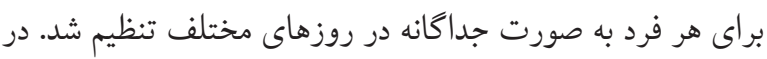

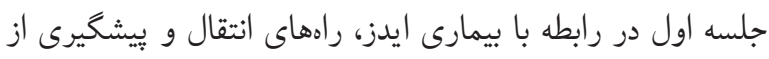

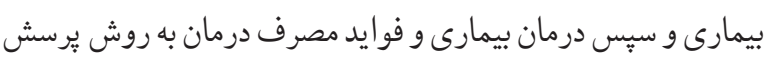

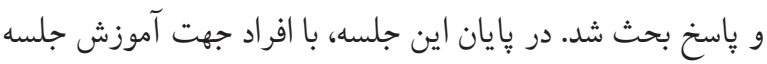

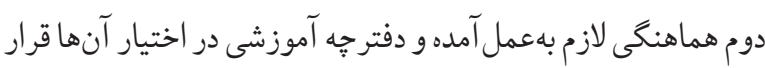
كرفت. بيرامون موانع مصرف دارو در جلسه دوم با افراد صحبت لازيت

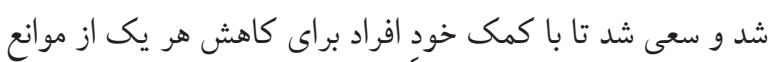

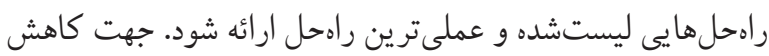

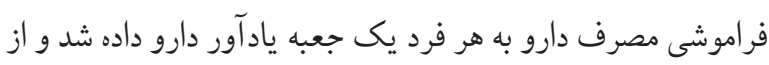

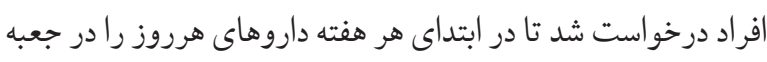

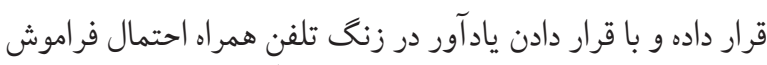

در مورد توانايى خود براى مصرف منظم داروى ضد رتروو يروسى در شرايط مختلف را بررسى مى كند (IF). يرسشنامه حمايت

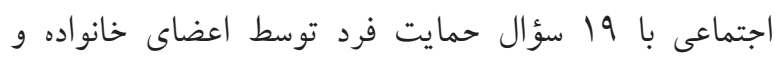
دوستان را در حيطه هاى مختلف روانى - عاطفى با مقياس ليكرت

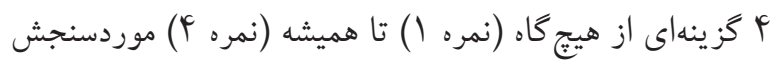

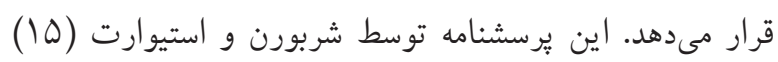

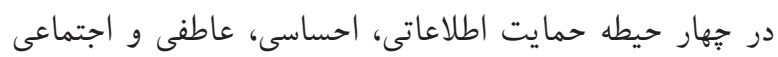
طر احىشده است. بخش سوم كيفيت زندگى را موردسنجش قرار مىدهد.

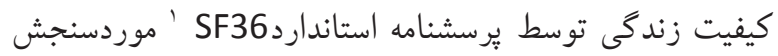
قرار كرفت. فرم وب عبارتى اين يُرسشنامه توسط شربون ئنس

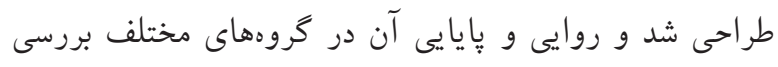

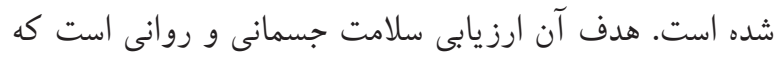

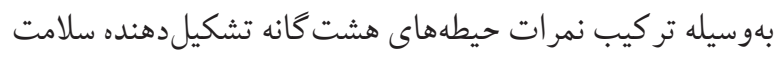

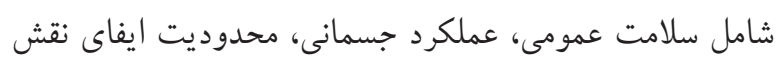

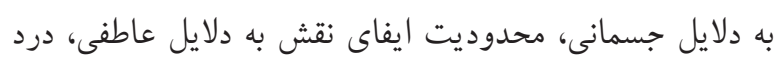

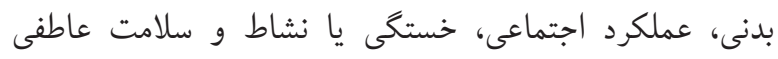

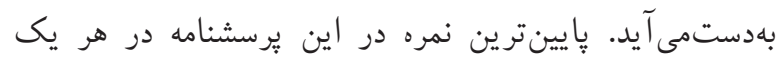

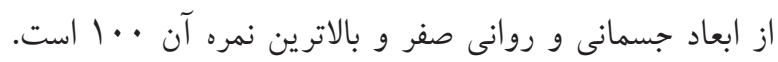

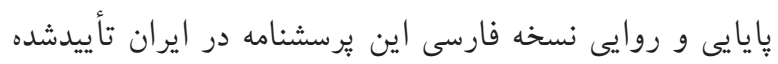

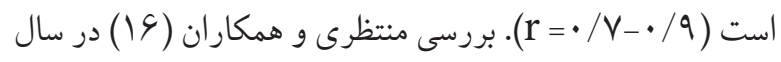

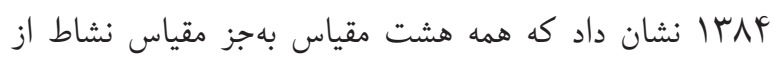
آلفاى كرونباخ بالاتر از V/ • برخوردار بودند.

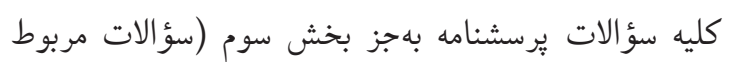
به كيفيت زندگى) در سه مرحله قبل، بلافاصله و سه ماه بعد از

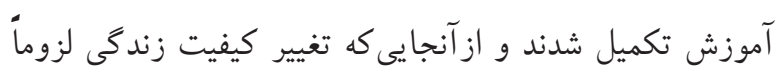

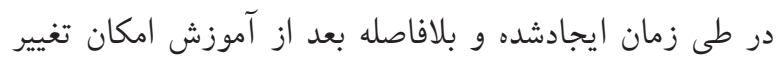

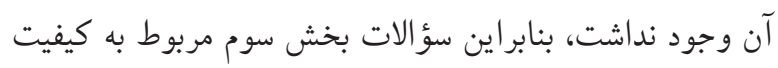

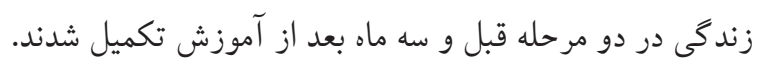

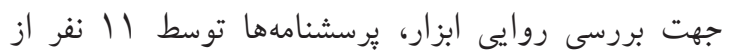


دو كروه ازنظر ويزگىهاى جمعيتشناختى و از آزمون آناليز

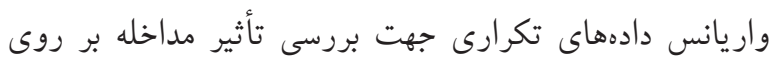
سازههاى الكوى ارتقاء سلامت و مقايسه تغييرات نمرات سازه در برد طول دوره آموزش و از آزمون تى زوجي جهت مقايسه ميانكين

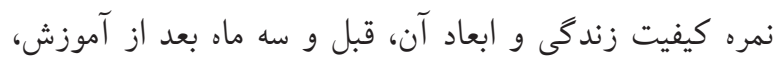

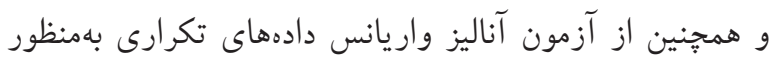

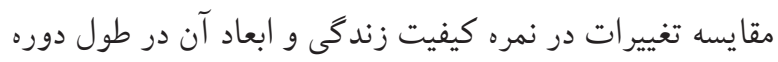
آموزش بين دو كروه استفاده شد.

يافته ها

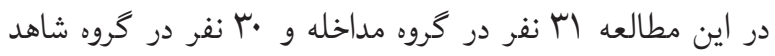

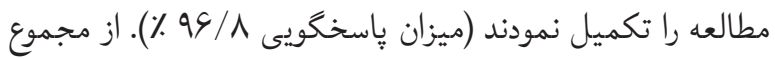

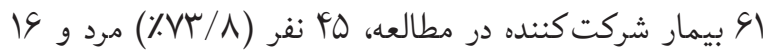

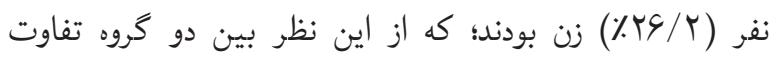

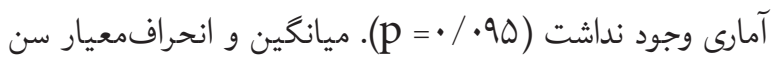
شركت كنندكان در كروه مداخله /

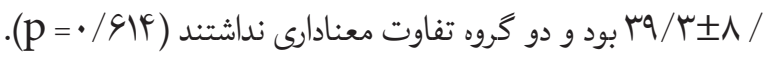
وضعيت دو كروه ازنظر ساير خصوصيات و تجربيات فردى قبل از مطالعه در جدول إنشان داده شده است.

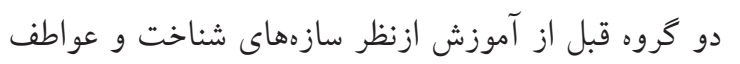
خاص رفتار تفاوت معنادارى نداشتند. آموزش مبتنى بر الكوى ارتقاء سلامت توانست كليه سازهها را بهطور معنادارى تغيير دهد؛

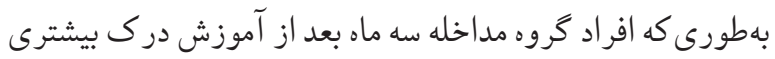
از حمايت خانواده، فوايد بايبندى به درمان و خود كار آمدى مبنى إنى بر بإيبندى به درمان داشته و احساسات افراد اين گروه نسبت به بهان درمان ضد رتروويروسى بهبوديافته بود. همجنين بهطور معنادارى

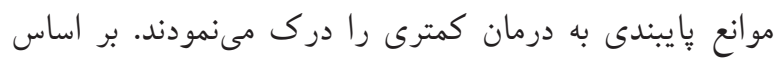

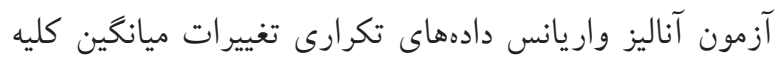

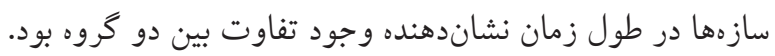

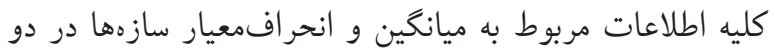
كروه در طول زمان در جدول ب نشان داده شده است.
كردنن دارو را كاهش دهند. در همين جلسه احساس افراد نسبت به مصرف دارو موردبررسى قرار كرفته و با بيان اهميت مصرف دارو دارئ

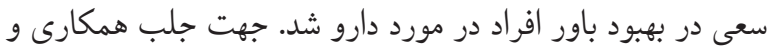

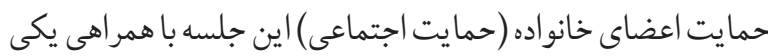
از اعضاى خانواده، معرفىشده توسط خود فرد در جلسه اول، بركزار

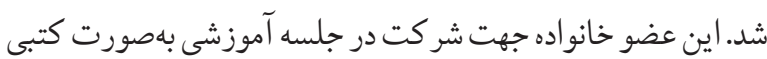
و همجنين با تماس تلفنى دعوت شد. جهت ارتقاء خودكار آمدى از ترغيب كلامى بهرهيرى شد. بهاينترتيب كه در ماه اول، هر هفته

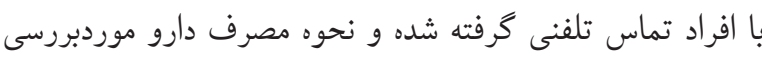

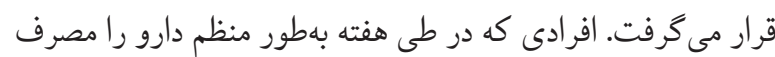

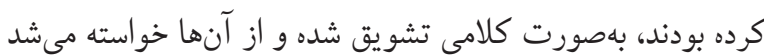
تا همجنان به مصرف دارو ادامه دهند. افرادى كه در تماس تلفنى مشخص مىشدند كه دارو را مصرف نمى كردند، يك جلسه آموزشى آنى ديكر (يك جلسه اضافى) جهت بررسى موانع مصرف و ارائه راهحل

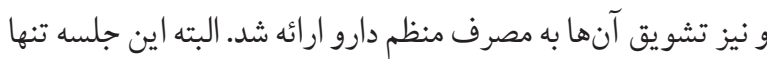
براى يك نفر بر كزار شد. تماس تلفنى براى افراد اين گرووه هر هفته تا يك ماه و سيس ماهانه تا بايان مطالعه (سه ماه) انجام شد. در پِايان دوره مطالعه (سه ماه بعد) افراد جهت تكميل برسشنامهها به مركز

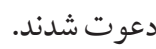
در كروه شاهد، بr نفر در ابتداى مطالعه جهت تكميل يرسشناهها به مركز مشاوره بيمارىهاى رفتارى دعوت شدند.

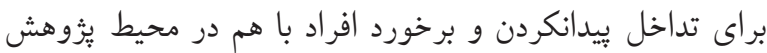

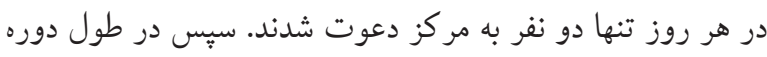

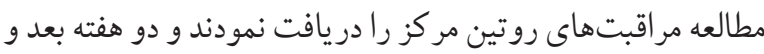
سبس سه ماه بعد جهت تكميل يرسشنامها به مر كز مر اجعه كردند. در اين كروه، دو نفر به علت عدم مراجعه بعدى از مطالعه خارج براج

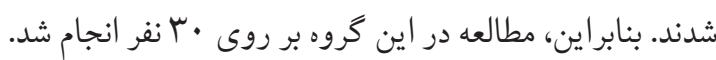

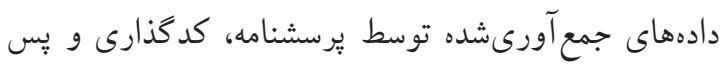
از ورود به كامييوتر توسط SPSS18 مورد تجز يهوتحليل قرار كرفتند. در تحليل دادهها علاوه بر ارائه شاخصهاى توريفى، از آزمونهاى تى مستقل و كاى اسكوئر بهمنظور بررسى همكنى 
جدول ا. وضعيت متغيرهاى مربوط به خصوصيات و تجربيات فردى به تفكيى دو گَروه در شروع مطالعه

\begin{tabular}{|c|c|c|c|c|}
\hline \multirow{3}{*}{$\begin{array}{l}\text { p value } \\
. / .90\end{array}$} & \multirow{3}{*}{ 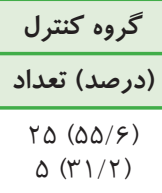 } & \multirow{3}{*}{ 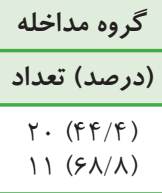 } & \multirow{2}{*}{\multicolumn{2}{|c|}{ خصوصيات و تجربيات فردى }} \\
\hline & & & & \\
\hline & & & 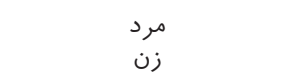 & 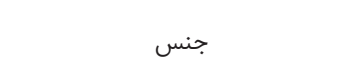 \\
\hline$\cdot / F T V$ & $\begin{array}{l}\Delta(r N / \Delta) \\
r(V \Delta) \\
r \mid(\Delta r / \Delta) \\
I(r \Delta)\end{array}$ & $\begin{array}{l}\Lambda(G \backslash / \Delta) \\
I(r \Delta) \\
19(F \vee / \Delta) \\
r(Y \Delta)\end{array}$ & 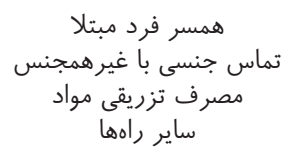 & راه انتقال بيمارى \\
\hline.$/ 1 \cdot 9$ & $\begin{array}{c}r \Delta(\Delta F / \mu) \\
\Delta(r r / \mu)\end{array}$ & $\begin{array}{l}r \mid(f \Delta / V) \\
1 \cdot(G S / V)\end{array}$ & دييلم و بالاتر & تحصيلات \\
\hline.$/ 94 \wedge$ & $\begin{array}{l}r \wedge(\Delta \cdot) \\
r\left(\mathcal{F}^{*}\right)\end{array}$ & $\begin{array}{l}r \wedge(\Delta \cdot) \\
r(\xi \cdot)\end{array}$ & خير & آكاهى خانواده از بيمارى \\
\hline.$/ 949$ & $\begin{array}{c}1(\Delta \cdot) \\
19(F \Delta / Y) \\
1 \cdot(\Delta N / \Lambda)\end{array}$ & $\begin{array}{l}I(\Delta \cdot) \\
r \Psi(\Delta F / \Lambda) \\
V(F \mid / Y)\end{array}$ & 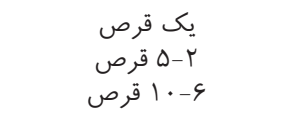 & تعداد قرص تجويزشده \\
\hline.$/ T \Delta$. & $\begin{array}{l}G(G G / V) \\
V(F \cdot) \\
\mathcal{F}(G \cdot) \\
\mid r(\mathcal{F} \cdot / G)\end{array}$ & $\begin{array}{l}\mu(\mu r / \mu) \\
\mu(\mu \cdot) \\
q(\xi \cdot) \\
19(\Delta q / \mathcal{F})\end{array}$ & 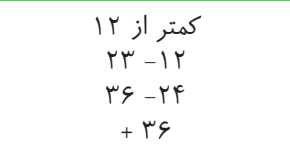 & طول مدت درمان (ماه) \\
\hline r & $\begin{array}{c}\wedge(\mathcal{F} \wedge / \mathcal{F}) \\
r Y(\Delta \wedge Y /)\end{array}$ & $\begin{array}{l}\text { I. }(\Delta \Delta / \varsigma) \\
r \mid(\& \wedge / \wedge)\end{array}$ & خير & سابقه عوارض جانبى \\
\hline$. / V \mid$ & $\begin{array}{l}\mid f(\Delta \mid / q) \\
\mid \&(F \vee / 1)\end{array}$ & $\begin{array}{l}\mid r(F \wedge / 1) \\
\mid \wedge(\Delta r / q)\end{array}$ & خلى & سابقه پِايبندنبودن به ART \\
\hline.$/ 0 \ldots$ & $\begin{array}{c}11(F F) \\
19(\Delta r / \Lambda)\end{array}$ & $\begin{array}{l}\operatorname{IF}(\Delta S) \\
\mid V(\mathcal{F} / T)\end{array}$ & خير & سابقه پايبندنبودن به ساير درمانها \\
\hline
\end{tabular}

جدول r. ميانگين و انحراف معيار سازههاى الگوى ارتقاء سلامت به تفكيى دو گروه در طول دوره مطالعه

\begin{tabular}{|c|c|c|c|c|}
\hline \multirow{2}{*}{ p value } & كروه كنترل & كروه مداخله & \multirow{2}{*}{ زمان } & \multirow{2}{*}{ سازهها } \\
\hline & انحرافمعيار 土 ميانگين & انحرافمعيار 土 ميانكين & & \\
\hline \multirow[t]{2}{*}{$>p \cdot / \cdots 1$} & $\begin{array}{l}r q / \cdot . \pm \Delta / q . \\
r q / r \cdot \pm \psi / \Lambda F \\
r F / / r \pm \Delta / r V\end{array}$ & $\begin{array}{l}r F / V V \pm \Delta / 1 . \\
\psi Y / q \cdot \pm \psi / l q \\
\psi r / \cdots \pm \psi / q q\end{array}$ & سلافاصله بعد از مداه مداخله ازله مداخله & احساس مرتبط به درمان \\
\hline &.$/ 194$ & $>\cdot \mathrm{p} / \cdots 1$ & \multicolumn{2}{|c|}{$\mathrm{p}$ value } \\
\hline \multirow[t]{2}{*}{$\cdot / \cdot \wedge \mathrm{F}$} & $\begin{array}{l}\mid r / q q \pm \Delta \cdot / r V \\
\mid r / \Lambda \Lambda \pm r q / \Delta . \\
\mid r / F r \pm F q / q .\end{array}$ & $\begin{array}{l}|G / \Psi \wedge \pm \Delta| / \cdot r \\
|\Delta / \wedge q \pm \Delta \mu / \vee| \\
|\Delta /| r \pm \Delta s / q \Psi\end{array}$ & سلافاصله بعد از مداز مداخله & حمايت خانواده و دوستان \\
\hline &.$/ 940$ &.$/ \cdots \wedge$ & \multicolumn{2}{|c|}{$\mathrm{p}$ value } \\
\hline \multirow[t]{2}{*}{.$/ \cdots 1$} & $\begin{array}{l}r r / V \Lambda \pm 99 / r V \\
r r / 19 \pm 9 r / . . \\
19 / 9 r \pm 9 \Delta / 9 .\end{array}$ & 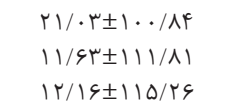 & سلافاصله بعد از مداه مداخله ازله مداخله & خود كار آمدى درك شده \\
\hline & . IFrs & $>\cdot \mathrm{p} / \cdot \cdot \mathrm{l}$ & \multicolumn{2}{|c|}{$\mathrm{p}$ value } \\
\hline \multirow[t]{2}{*}{$\cdot / \cdots 1$} & $\begin{array}{l}r / r f \pm r l / q r \\
r / r q \pm r \cdot / \Lambda . \\
r / \Lambda \subseteq \pm r I / / r\end{array}$ & $\begin{array}{l}r / G \mu \pm Y r / r r \\
1 / V \Lambda \pm r F / 1 . \\
\cdot / r \Delta \pm r F / q r\end{array}$ & سلافاصله بعد از مداه مداخله ازله مداخله & فوايد دركشده \\
\hline &.$/ 10$ & $>\cdot \mathrm{p} / \cdot \cdot 1$ & \multicolumn{2}{|c|}{$\mathrm{p}$ value } \\
\hline \multirow[t]{2}{*}{.$/ .1$} & 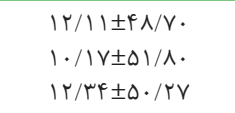 & $\begin{array}{l}\mid r / \Lambda \Delta \pm \Delta \Delta / \Delta r \\
1 \cdot / r \mid \pm r \Delta / F \Delta \\
11 / r \cdot \pm r r / V V\end{array}$ & سلافاصله بعد از مداز مداخله ازله مداخله & موانع دركشده \\
\hline & . $/$ r & $>\cdot p / \cdot \cdot 1$ & \multicolumn{2}{|c|}{$\mathrm{p}$ value } \\
\hline
\end{tabular}


نتايج مطالعه نشان داد كه آموزش مبتنى بر الخوى ارتقاء در گروه مداخله توانست كيفيت زندگى در ابعاد عملكرد جسمى،

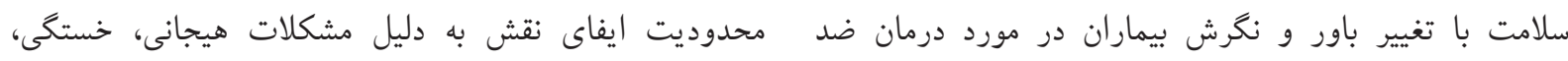

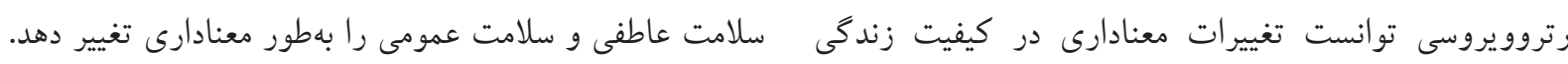

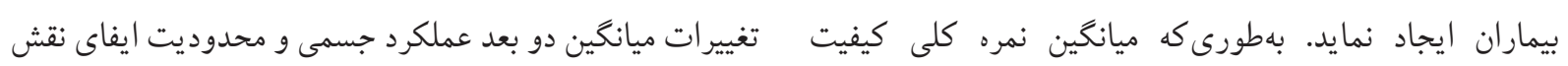

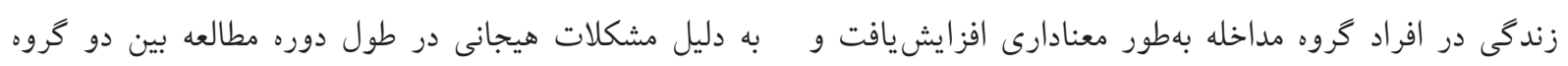

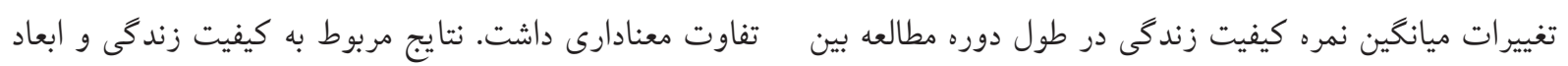

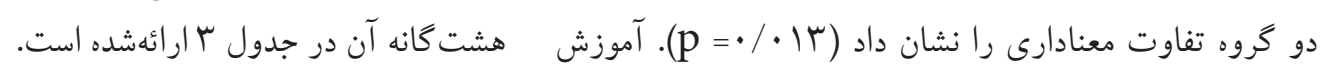
جدول س. ميانكَين و انحرافمعيار كيفيت زندَّى و ابعاد آن به تفكيك دو كَروه در طول دوره مطالعه

\begin{tabular}{|c|c|c|c|c|}
\hline \multirow{2}{*}{$p$ value } & كروه كنترل & كروه مداخله & \multirow{2}{*}{ زمان } & \multirow{2}{*}{ كيفيت زندكى و ابعاد هشت كانه آن } \\
\hline & انحرافمعيار 土 ميانگين & انحرافمعيار 土 ميانكين & & \\
\hline \multirow[t]{2}{*}{ ( } & $\begin{array}{l}\Delta \Delta / \cdot r \pm r r / q \Delta \\
\Delta r / r \Delta \pm r \Delta / \Delta r\end{array}$ & $\begin{array}{l}\Delta Q / r s \pm r \mid / \Delta r \\
V r / r \cdot \pm \mid q / \cdot V\end{array}$ & سه ماه بعد از مداخله مداخله & كيفيت زندگى \\
\hline & . /AFF &.$/ .1$ & \multicolumn{2}{|r|}{$\mathrm{p}$ value } \\
\hline \multirow{2}{*}{$\cdot / \cdot r$} & $\begin{array}{l}S N / Y r \pm r r / V Q \\
V \cdot / A r \pm Y r / r q\end{array}$ & $\begin{array}{l}S Q / r \Delta \pm r F / \wedge \varphi \\
\wedge r / V^{F} \pm 1 \Lambda / \wedge \Lambda\end{array}$ & سه ماه بعد از مداخله & بعد عملكرد جسمانى \\
\hline & . /OrA & $>\cdot \mathrm{p} / \cdot \cdots 1$ & \multicolumn{2}{|r|}{$\mathrm{p}$ value } \\
\hline \multirow{2}{*}{$\cdot / f F r$} & 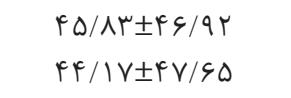 & $\begin{array}{l}F G / \Lambda \cdot \pm F V / T . \\
\Delta \Lambda / A V \pm F N / \Delta F\end{array}$ & سه ماه بعد از مداخله & حدوديت ايفاى نقش به دليل مشكلات جسمى \\
\hline & $\cdot / 1 \Delta \Delta$ & . ITHO & \multicolumn{2}{|r|}{$p$ value } \\
\hline \multirow[t]{2}{*}{$\cdot / \cdot r$} & $\begin{array}{l}r N / \wedge q \pm r \wedge / \cdot 1 \\
r \Delta / \Delta \Delta \pm r q / / r\end{array}$ & $\begin{array}{l}r \cdot / \Lambda s \pm r \varepsilon / 11 \\
\vee Q / \Delta V \pm r \cdot / \cdot V\end{array}$ & سه ماه بعد از مداخله & محدوديت ايفاى نقش به دليل مشكلات \\
\hline &.$/ 490$ &.$/ .1$ & \multicolumn{2}{|r|}{$\mathrm{p}$ value } \\
\hline \multirow[t]{2}{*}{$\cdot / \cdot \Delta \mu$} & $\begin{array}{l}\Delta 1 / \Delta \cdot \pm r r / q . \\
\Delta r / \cdot \cdot \pm r \Delta / q \Delta\end{array}$ & 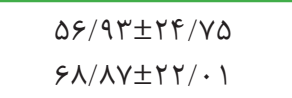 & سه ماه بعد از مداخله مداخله & خستخى يا نشاط \\
\hline &.$/ 914$ &.$/ .11$ & \multicolumn{2}{|r|}{$\mathrm{p}$ value } \\
\hline \multirow[t]{2}{*}{$\cdot / \cdot v \Delta$} & $\begin{array}{l}\Delta 1 / 9 \cdot \pm r F / q \Lambda \\
\Delta r / T r \pm r \Delta / \cdot q\end{array}$ & $\begin{array}{l}91 / r q \pm r r / r r \\
V r / 1 r \pm 19 / V V\end{array}$ & سه ماه بعد از مداخله & سلامت عاطفى \\
\hline &.$/ 9 \ldots$ &.$/ . r s$ & \multicolumn{2}{|r|}{$\mathrm{p}$ value } \\
\hline \multirow[t]{2}{*}{.$/ F q F$} & $\begin{array}{l}\Delta \Delta / \cdots \pm r r / r g \\
\Delta \cdot / \cdots \pm r I / \Lambda r\end{array}$ & 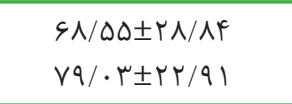 & سه ماه بعد از مداخله & عملكر د اجتماعى \\
\hline & ( & .1 .94 & \multicolumn{2}{|r|}{$\mathrm{p}$ value } \\
\hline \multirow[t]{2}{*}{ •/var } & $\begin{array}{l}G F / F r \pm r \cdot / r F \\
G Y / \cdot \wedge \pm \Psi F / G r\end{array}$ & $\begin{array}{l}S V / q \cdot \pm r M / \cdot F \\
G N / \Delta \Delta \pm \Psi F / N I\end{array}$ & سه ماه بعد از مداخله مداخله & ل درد \\
\hline & . /orq &.$/ 94$ & \multicolumn{2}{|r|}{$\mathrm{p}$ value } \\
\hline \multirow{2}{*}{$\cdot / l \Delta \mu$} & $\begin{array}{l}S Y / G V \pm r r / G G \\
\Delta Q / \cdots \pm r r / r G\end{array}$ & $\begin{array}{l}S Y / 4 Y \pm 19 / 99 \\
V G / 91 \pm 19 / \Delta 9\end{array}$ & سه ماه بل ازد مداخله مداخله & 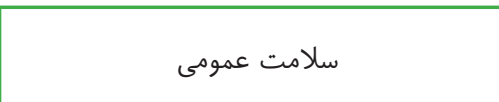 \\
\hline &.$/ 199$ & $\cdot / \cdots 1$ & \multicolumn{2}{|r|}{$\mathrm{p}$ value } \\
\hline
\end{tabular}


درمان، خود را افزايش مىدهند؛ كه موجب بهبود كيفيت زندكى آنها مىشود(19).

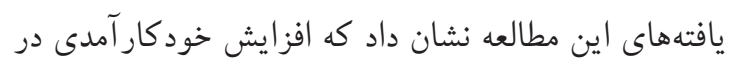

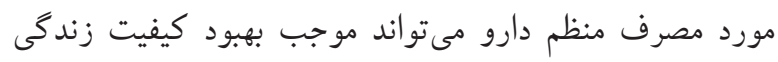

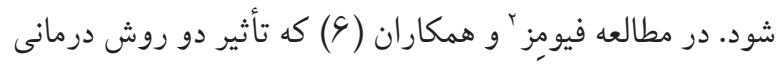

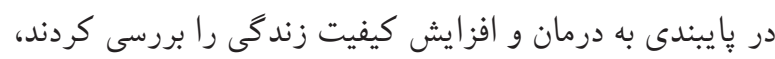
مشخص شد در گروهى كه درى بيشترى از خودكار آمدى به به ديه

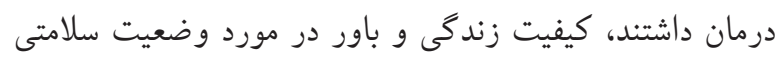
بهترى داشتند؛ كه اين يافتهها همراستا با نتايج اين مطالعه است.

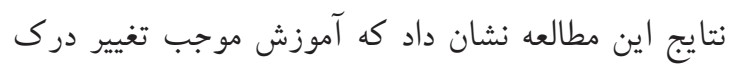

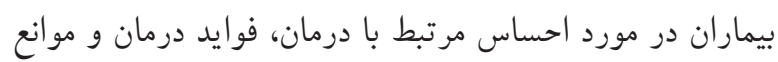
مصرف منظم درمان مىشود و از اين طريق كيفيت زندگى بـى دوردان

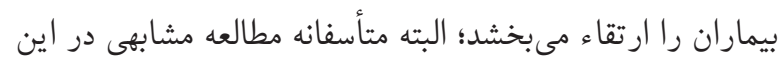

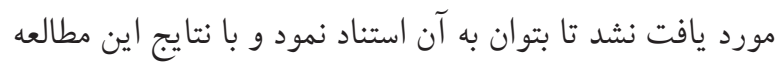

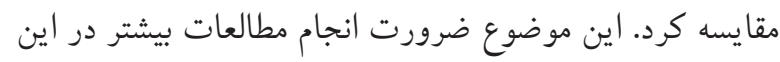
زمينه را مشخص مى كند.

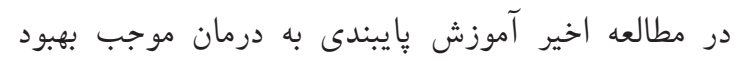

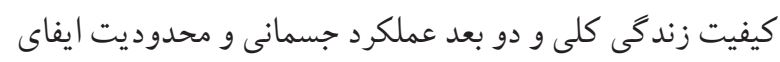

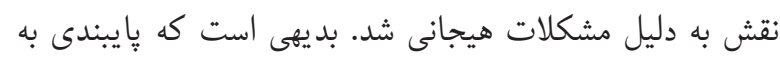

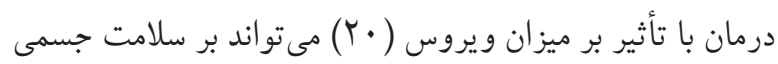

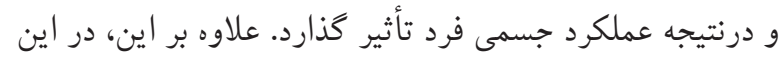

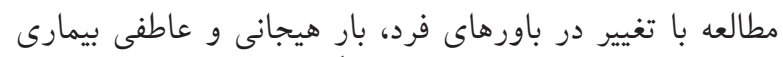

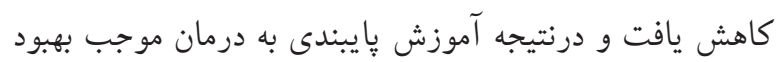

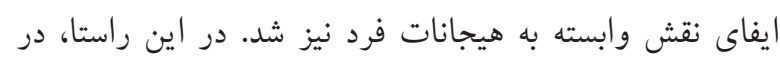

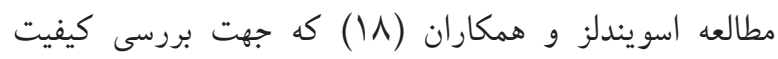
زندگى بيمارانى ايدزى انجام شده بود، مشخص كرديد كه بعد اندان

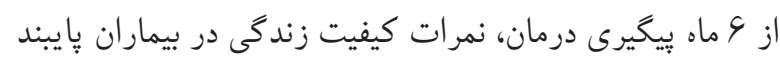
به درمان · ب٪ افزايش يافت. نتايج مطالعه افهمى و همكاران

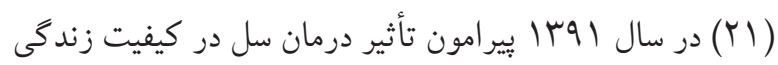

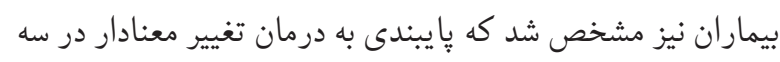
اين مطالعه با هدف تعيين تأثير آموزش پايبندى به درمان مبتنى

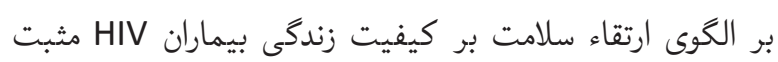

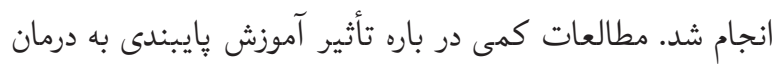

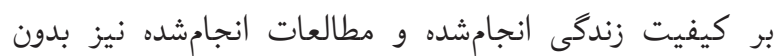

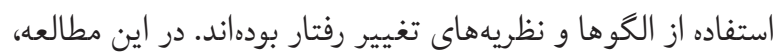
آموزش پايبندى به درمان بر اساس الخوى ارتقاء سلامت توانست

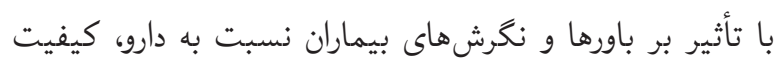

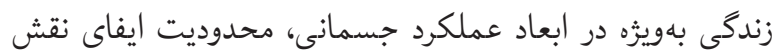

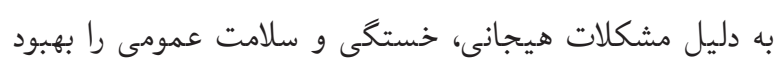
دهد. البته در طول دوره مطالعه، بين دو گروه بهجز وضعيت كلى ولى دلى

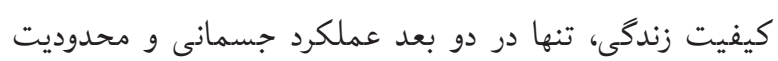
ايفاى نقش به دليل مشكلات هيجانى تفاوت ايجادشده بود.

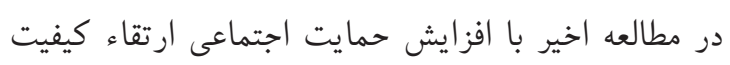

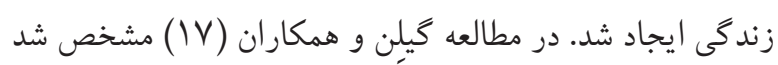
كه بين كيفيت زندگى و حمايت اجتماعى ارتباط وجود دارد دارد؛

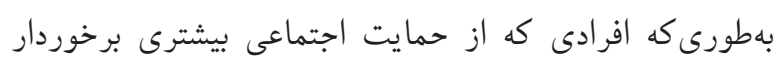

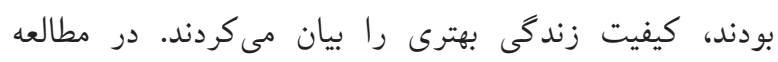

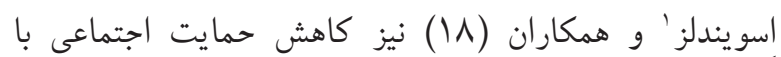
كاهش كيفيت زندگى در بيماران همراه بود؛ كه مؤيد يافتهاى هاى مطالعه اخير است. حمايت اجتماعى، كيفيت زندگى بيماران

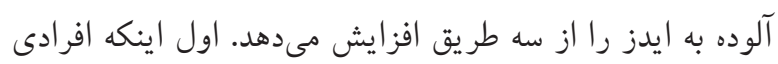

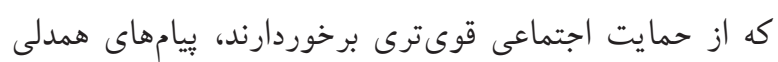

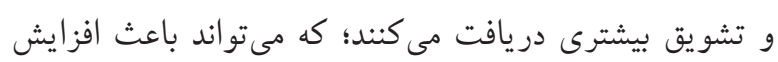

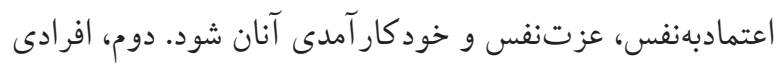
كه فاقد حمايت اجتماعى هستند، بيشتر به رفتارهايى مانند سيكار

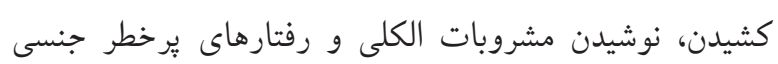

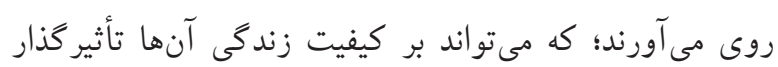

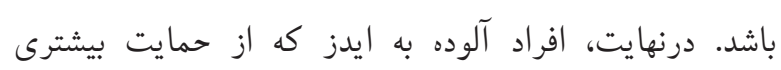

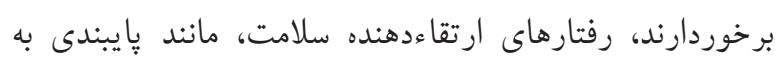


ازجمله محدوديتهاى اين مطالعه دوره يِيخيرى كوتاهمدت

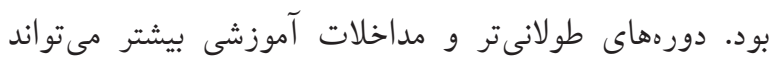

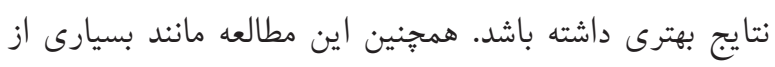

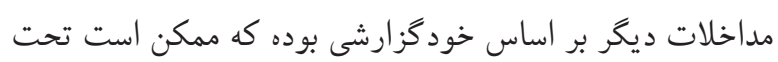

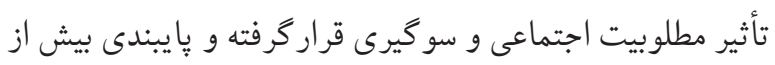
ميزان واقعى آن كزارش شده باشد.

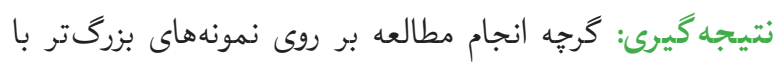

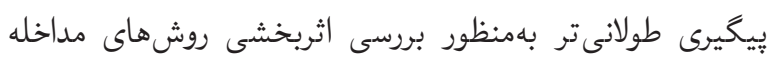

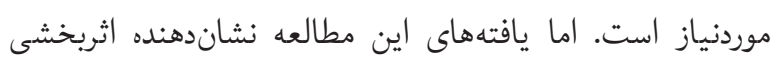

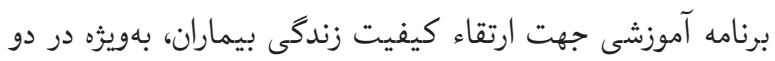
بعد عملكرد جسمانى و محدوديت ايفاى نقش ناشى از مشكلات

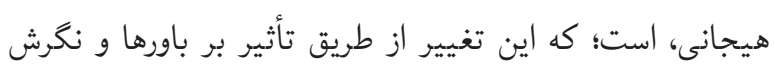
بيماران در مورد يايبندى به درمان بهدست كمى آيد.

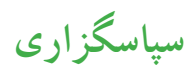
اين يُزوهش بركرفته از ياياننامه مقطع كارشناسىارشد آموزش

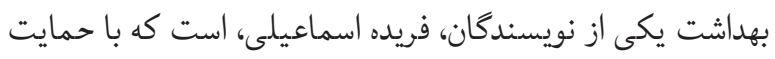
مالى معاونت يُزوهشى دانشكاه علوم يزشكى بوشهر انجام كرديد.

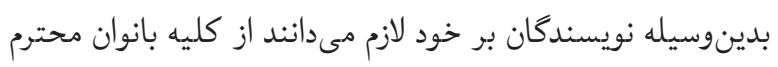
شركت كننده در اين مطالعه كه با صبورانه در اين مطالعه شركت كردند مراتب تشكر و قدردانى را به عمل آورند.

\section{References:}

1. The Gap Report. Unaids Data 2013 )http//:www.unaids. org).

2. Newsletter management of communicable diseases in the context of HIV 2014.

3. Haery SM, Tehrani H, Olyaeimanesh A, Nedjat S. Factors Influencing the Social Health of Employees of the Ministry of Health and Medical Education in Iran. Iranian Journal of Health Education and Health Promotion. 2016;3(4):3118.. [Persian]

4. Mazloomy Mahmoodabad SS, Tehrani H, Gholian-aval M, Gholami H, Nematy M. The effect of social class on the amount of salt intake in patients with hypertension. Blood pressure. 2016;25(6):360-3.

5. Mannheimer S.B, Matts J, Telzak E, et al. Quality of life in HIV-infected individuals receiving antiretroviral therapy is
بعد سلامت جسمى، اجتماعى و روحى -روانى ايجاد مى كند؛ كه

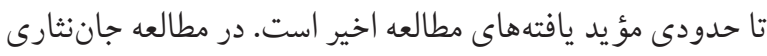

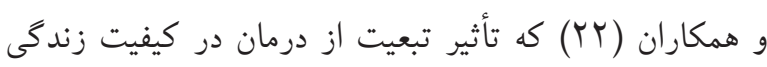

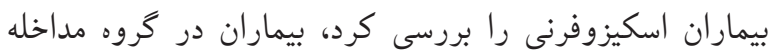

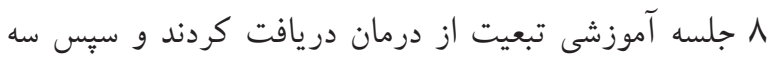

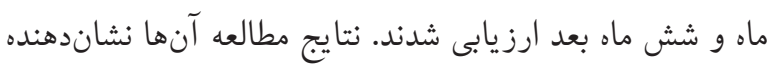
تغييرات معنادار در ميانكين نمرات كيفيت زندگى ماهى و و و ماه بعد از مداخله بود؛ كه مؤيد يافتههاى مطالعه اخير است. البته به

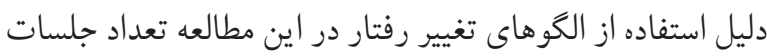

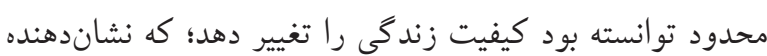
اثربخشى الكوى استفادهشده در اين زمينه است. بااينوجودد، تأثير

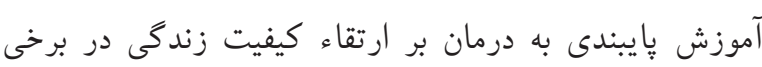

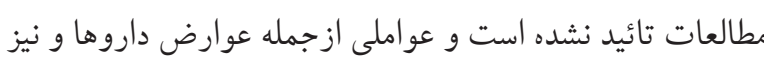
خستهشدن بيمار از تداوم در مصرف دارو عامل مؤثر شناسايى

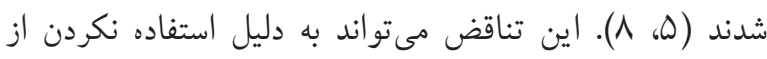

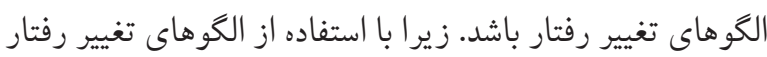

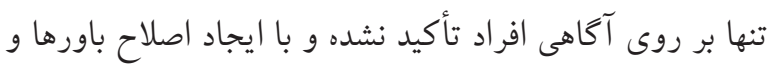

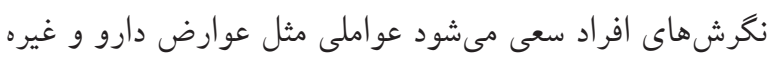

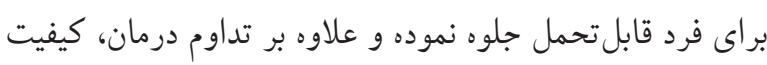
زندگى بهترى را بيان كنند.

related to adherence. AIDS Care 2005; 17(1): 10-22.

6. Fumaz C, Tuldra A, Ferrer M, et al. Quality of Life, Emotional Status, and Adherence of HIV-1-Infected Patients Treated With Efavirenz Versus Protease. Inhibitor-Containing Regimens. J Acquir Immune Defic Syndr 2002; 29: 244-253.

7. Nieuwkerk PT, Gisolf EH, Reijers $\mathrm{MH}$, et al. Long-term quality of life outcomes in three antiretroviral treatment strategies for HIV-1 infection. AIDS 2001;15:1985 - 1991.

8. Goujard C, Bernard N, Sohier N, et al. Impact of a patient education program on adherence to HIV medication. J Acquir Immune Defic Syndr 2003;34(2):191-4.

9. Pender NJ. Health Promotion in nursing practice. Fourth edition, Upper Saddle River NJ: Prentic Hall, 2002.

10. Noroozi A, Tahmasebi R, Ghofranipour F, Hydarnia A. Effect of Health Promotion Model (HPM) Based Education 
on Physical Activity in Diabetic Women. Iran J Endocrin Metab 2011; 13(4):361-367.

11. Smith MY, Rapkin BD, morrison A, Kammerman S. Zidovudine adherance in persons with aids: The Relation of Patient Beliefs About Medication to Self-Termination of Therapy. J Gen Internal Med 1997:12 (4): 216-223.

12. Horne R, Weinman J, Hankins M. The Beliefs about Medicines Questionnaire: The development and evaluation of a new method for assessing the cognitive representation of medication. Psychol Health, 1999: 14: 1-24.

13. Duong $M$, Piroth $L$, Grappin $M$, et al. Evaluation of the Patient Medication Adherence Questionnaire as a Tool for Self-Reported Adherence Assessment in HIV-Infected Patients on Antiretroviral Regimens. HIV Clin Trials, 2001: 2(2):128-135.

14. Johnson MO, Neilands TB, Dilworth S, et al. The Role of Self-Efficacy in HIV Treatment Adherence: Validation of the HIV Treatment Adherence Self-Efficacy Scale (HIVASES). J Behav Med, 2007: 30(5): 359-370.

15. Sherbourne CD, Stewart A. The MOS social support survey. Soc Sci Med 1991: 32(6): 705-714.

16. Montazeri A, Goshtasbi A, Vahdaninia MAS. The short form health survey (SF-36): Translation and validation study of the Iranian version. Payesh 2006;5(1):49-56. [Persian]
17. Gielen AC, McDonnell KA, Wu AW, O'campo P, Faden R. Quality of life among women living with HIV: the importance violence, social support, and self care behaviors. Soc Sci Med, 2001 Jan 31;52(2):315-22. http:// dx.doi.org/10.1016/S0277-9536(00)00135-0

18. Swindells S, Mohr J, Justic JC. Quality of life in patients with human immune deficiency virus infection: Impact of social support, coping style and hopelessness. Int J STD \& AIDS 1999;10 (6):383 - 391.

19. Heckman TG. The Chronic Illness Quality of Life (CIQOL) Model: Explaining Life Satisfaction in People Living With HIV Disease. Health Psychol 2003;22(2): 140-147

20. Chiou PY, Kuo B, Lee $M B$, et al. A program of symptom management for improving quality of life and drug adherence in AIDS/HIV patients. J Adv Nurs 2006: 55(2):169-179.

21. Afhami SH, Hamidi Farahani R, Rasolinejad M, et al. Evaluation of treatment effect of anti-tuberculosis drugs on the quality of life among tuberculosis patients admitted in Imam Khomeini hospital in Tehran. Ann Mil Health Sci Res 2012:10(4): 299-307. [Persian]

22. Jannesari Z, Omranifard V, Meraci M. The effect of compliance therapy on quality of life and global function of schizophrenic patients. J Res behav Sci 2011; 9(2):114122. [Persian] 